\title{
Fra datasæt til journalistik Et kvalitativt studie af danske datajournalisters legitimeringspraksis og epistemologi
}

AF BOY RASMUS REPENNING

\section{Resumé}

På baggrund af otte semi-strukturerede interviews med danske datajournalister undersøger artiklen, hvordan datajournalister begrunder og retfærdiggør deres praksis i forhold til oversættelsen af kvantitative data til journalistik. Særligt fokuseres der på, hvordan journalisterne retfærdiggør eventuelle lån af metoder og logikker fra discipliner uden for den journalistiske profession. Indsigterne bruges til at opridse epistemologien bag datajournalistikken, altså de normer, regler og procedurer, der styrer vidensproduktionen. Artiklen konkluderer, at datajournalisternes epistemologiske overvejelser er præget af en høj grad af pragmatisme, samt at journalistiske rationaler sætter tydelige rammer for importen af metoder og logikker fra andre discipliner.

\section{Introduktion}

Tal og data er allestedsnærværende i journalistikken og langtfra et nyt syn. Den såkaldte datajournalistik, her bredt forstået som produktionen af journalistik med afsæt i kvantitative data, går imidlertid et skridt videre og gør arbejdet med data til selve omdrejningspunktet for journalistens arbejde (Coddington, 2015: 332). Et skridt, der ikke blot har betydning for datajournali- 
sternes arbejdsproces, men også for den måde, hvorpå datajournalistik præsenteres og formidles.

I et forskningsøjemed rejser skridtet ikke mindst problemstillinger vedrørende datajournalistikkens epistemologi. Spørgsmålet er med andre ord, på hvilket grundlag og ud fra hvilke kriterier datajournalisterne kan retfærdiggøre deres talknuseri. Som al journalistik handler datajournalistik om at frembringe troværdiggjort viden om virkeligheden, og epistemologien betegner det sæt af regler, rutiner og institutionaliserede procedurer, der bestemmer, hvilken form for (journalistisk) viden der bliver produceret, og hvordan vidensproduktionen legitimeres (jf. Ekström, 2002: 260, Parasie, 2015: 373).

Denne artikel har til formål at belyse nogle af datajournalistikkens epistemologiske grundtræk samt de logikker og afvejninger, der kendetegner journalisternes metodiske og formidlingsmæssige valg. Artiklen gør dette ved at undersøge, hvordan danske datajournalister retfærdiggør deres praksis i forhold til produktionen af datajournalistik.

\section{Datajournalistikkens professionelle rammer og vidensgrundlag}

Datajournalister arbejder som andre professionelle aktører næppe i et vakuum. En analyse af, hvordan aktørerne legitimerer deres praksis, bliver derfor nødt til at skele til det professionelle menings- og vidensystem, som datajournalisterne agerer inden for.

Ifølge professionssociologen Andrew Abbott (1988) er grundlaget for en profession og den professionelle praksis et abstrakt vidensgrundlag, som professionens medlemmer anvender i konkrete sager, og som kan bruges til at afgrænse professionens ansvars- og opgaveområde (Abbott 1988: 6ff). Betragtes det journalistiske arbejde med data som en professionel praksis, bliver koblingen mellem valg og vidensgrundlaget for alvor synlig i de tilfælde, hvor journalisterne skal foretage et professionelt skøn (Grimen, 2008: 74; Svith, 2014: 119). For journalisters vedkommende kan for eksempel vinklingen og formidlingen af en historie betragtes som et skøn, idet journalisten under forudsætning 
af en vis handlingsautonomi og i fraværet af klare retningslinjer kan vælge mellem principielt lige gode handlingsalternativer (Grimen og Molander, 2008: 182).

Vidensgrundlaget bag den professionelle praksis kan være heterogen i den forstand, at det er sammensat af elementer fra forskellige discipliner (Grimen, 2008: 72). Det indebærer, at journalister kan låne konkrete og abstrakte videnselementer fra andre fagdiscipliners vidensgrundlag til at legitimere deres professionelle praksis (ibid.). For datajournalisters vedkommende kan disse elementer eksempelvis være metoder til den statistiske dataanalyse. Vidensgrundlagets sammensatte karakter begrebsliggøres i det følgende ved hjælp af begrebet vidensrationaler, der indgår som delelementer i vidensgrundlaget (Svith, 2014: 123). Vidensrationaler skal forstås som nogenlunde kohærente systemer af relativt abstrakte logikker, principper og begreber, der tilsammen former en grundlæggende fortælling om journalistens rolle og rationalet bag den journalistiske praksis (ibid.). Rationalerne indikerer eksempelvis, hvilke metoder og logikker indeholdt i vidensgrundlaget der bør anvendes i en bestemt situation.

\section{Strømninger og vidensrationaler i datajournalistikken}

Begrebet vidensrationaler er det analytiske udgangspunkt for dette studie af datajournalistikkens epistemologi. Generelt er den eksisterende litteratur om journalistikkens "kvantitative drejning" (jf. Coddington, 2015) kendetegnet ved, at der omtales en række distinkte, men ikke desto mindre beslægtede og til tider overlappende strømninger med tilknyttede epistemologiske rationaler. Mere specifikt kan der med afsæt i litteraturen skitseres tre centrale vidensrationaler med betydning for den videre analyse: et videnskabeligt, et datadrevet og et open source-inspireret (jf. figur 1). 
Figur 1. Forskellige vidensrationaler influerer på datajournalistikkens vidensgrundlag.

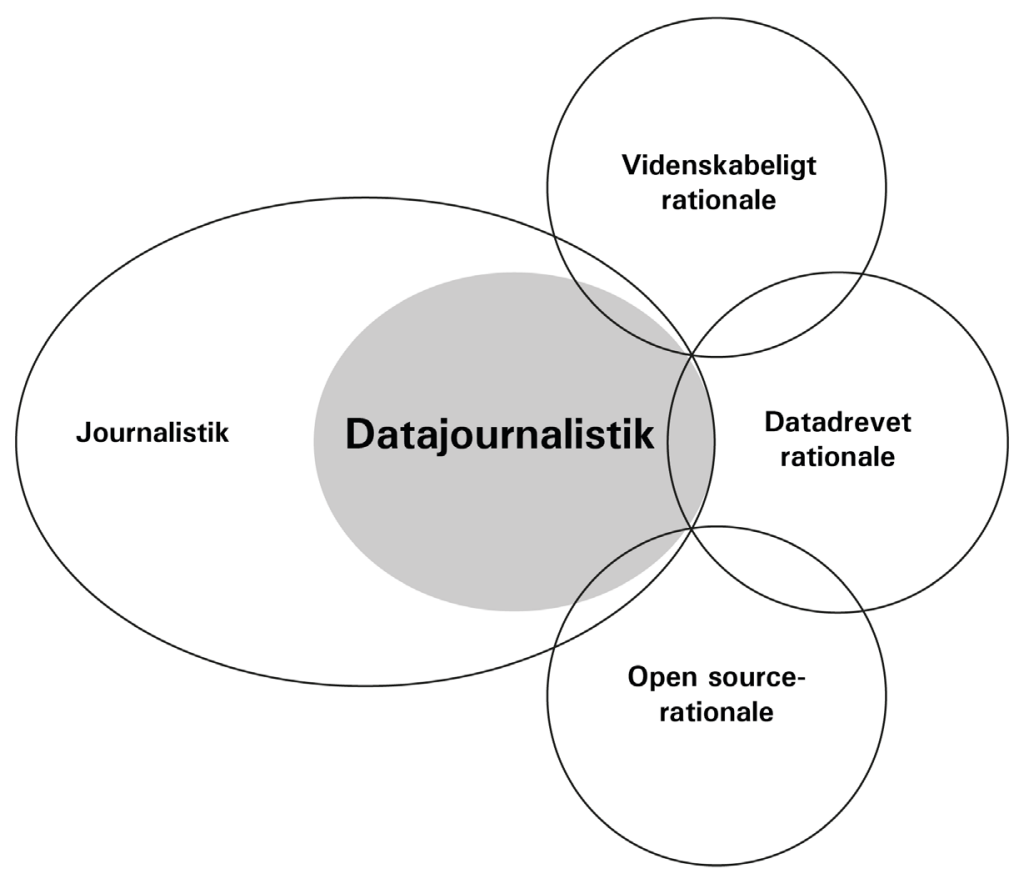

\section{Det videnskabelige}

Som de tidligste eksempler på datajournalistiske tendenser nævnes ofte de tæt relaterede strømninger "computer-assisted reporting" (CAR) og "precision journalism". Disse er kendetegnet ved, at de tilstræber anvendelsen af samfundsvidenskabelige metoder og databehandling med journalistisk formål i et forsøg på at øge journalistikkens præcision og objektivitet (Meyer, 1973: 2f; Wien, 2005). For den epistemologiske tilgang betyder importen af disse metoder, at CAR i endnu højere grad end andre former for journalistik bygger på en grundlæggende positivistisk epistemologi og den heri liggende antagelse, at man ved hjælp af empiriske observationer og kvantitative metoder kan komme tættere på en objektiv forståelse af virkeligheden (Hanitzsch, 2007: 376; Wien, 2005: 43). CAR-traditionen adopterer ligeledes et videnskabeligt præget objektivitetsideal, hvor en systematisk 
fremgangsmåde, transparens og frem for alt replicerbarhed er alfa og omega (Meyer, 1991: 13; Post, 2015: 731).

\section{Det datadrevne}

Mens CAR først og fremmest indebar brugen af videnskabelige metoder, har muligheden for at indsamle og behandle store mængder data på det seneste banet vejen for en mere datadrevet tilgang til selve dataanalysen, som blandt andet skitseres i Sylvain Parasies (2015) studie af amerikanske "programmer-journalists". Den datadrevne tilgang er i sin kerne mere induktiv og medfører i et vist omfang en radikal omfortolkning af journalistens rolle, idet journalistens opgave i mindre grad bliver at fortolke data, men i højere grad at skabe rammevilkårene for, at brugerne selv kan foretage analyser (Parasie og Dagiral, 2012: 865). Dette forudsætter en øget grad af interaktivitet i formidlingen samt en mere omfattende præsentation af datasæt, der tillader en individualiseret, brugerdrevet analyse af sidstnævnte (Parasie og Dagiral, 2012: 867ff).

\section{Det open source-inspirerede}

Endelig fremhæves i litteraturen datajournalistikkens tætte bånd til open source-kulturen, der oprindeligt har sine rødder i it-verdenen og den kollektive og decentrale udvikling af software (Greene, 2015; Parasie og Dagiral, 2012: 866). Ifølge de amerikanske medieforskere Nikki Usher og Seth Lewis (2013) kan open source-kulturens karaktertræk især spores i en grundlæggende åbenheds-etos, der omgiver datajournalistikken, og som tilskynder en større åbenhed omkring kilder og data (Coddington, 2015: 332f; Vos og Craft, 2016: 8). Det journalistiske arbejde ses som en åben proces, hvor forskellige aktører opfordres til at supplere og videreudvikle det journalistiske produkt (Greene, 2015). Den journalistiske vidensproduktion er dermed ikke afsluttet i det øjeblik, et produkt publiceres, men der er tale om et kontinuerligt samarbejde (Lewis og Usher, 2013: 609). 


\section{Metode}

Empirisk bygger undersøgelsen på 8 semi-strukturerede interviews med danske datajournalister (IP1-IP8), der med undtagelse af et enkelt besøgsinterview blev gennemført via telefon i løbet af april 2016 og havde en varighed på 30 til 60 minutter.

Gruppen af danske datajournalister blev identificeret gennem internetsøgninger på termer som "datajournalist" samt ved hjælp af bylines på datajournalistiske publikationer. Publikationerne blev blandt andet fundet via Facebook-gruppen „Datajournalistik“, der er målrettet nordiske datajournalister, samt ved at nærlæse listen over nominerede til de årligt uddelte NODA-Awards (tilgængelig på nodabase.net). Yderligere interviewpersoner blev identificeret ved at spørge de initialt udvalgte datajournalister om navne på andre personer, der beskæftiger sig med datajournalistik i en dansk kontekst (snowball-metoden). I alt blev 11 personer kontaktet, og rekrutteringen blev afsluttet, da interviewpersonerne i overvejende grad henviste til de samme personer. Allerede fordi datajournalistikkens afgrænsning er omtvistet og flydende, omfatter dette udvalg formentlig ikke samtlige personer, der på den ene eller den anden måde arbejder med datajournalistik i Danmark. Det vurderes dog, at en stor del af de mest relevante aktører (personer og/eller medier) er omfattet af undersøgelsen.

Idet flere af de interviewede journalister har arbejdet for forskellige medier, repræsenterer journalisterne et bredt udsnit af det danske medielandskab med større og mindre dagblade (bl.a. Politiken, Berlingske, Information), fagblade (bl.a. Computerworld, Ugeskrift for Læger), tv-medier (TV 2, DR) og rene webmedier (Bias.nu, Finans.dk).

Interviewene blev gennemført med afsæt i en overordnet interviewguide, der foruden en række baggrundsspørgsmål rummede relativt åbne spørgsmål om overvejelserne bag datajournalisternes (legitimerings)praksis (f.eks.: Hvornår er en særskilt metoderedegørelse nødvendig? Hvilke faktorer kigger du på, når du vurderer troværdigheden af et datasæt? Hvorvidt og hvornår spørger du eksterne eksperter til råds?). Så vidt muligt blev der herved spurgt ind til konkrete eksempler fra interviewpersonens arbejde. 
Efter transskriberingen blev materialet indledningsvis kodet tekstnært, hvorefter der ud fra den mere induktive kodning blev defineret koder for kategorier (f.eks. „åbenhed“) og underemner (f.eks. „forbehold over for åbenhed“). Disse koder blev brugt til en mere deduktiv genkodning af materialet. For at kontrollere kodningens konsistens blev tilfældigt udvalgte dele af interviewene genkodet efter et stykke tid, hvilket ikke viste nogen nævneværdig diskrepans.

Som et yderligere valideringstrin blev der gennemført en såkaldt medlemsvalidering (Brinkmann, 2012: 87), hvilket indebar, at de interviewede journalister fik mulighed for at kommentere og uddybe eventuelle citater og fortolkninger, der blev udledt af deres interviewudtalelser. Interviewpersonerne er anonymiseret, både for at undgå et for tydeligt fokus på enkeltpersoner og for at facilitere en mere ufiltreret dialog om eventuelle pragmatiske "smutveje".

Brugen af interviews betyder, at det er interviewpersonernes artikulerede refleksioner, der er det analytiske omdrejningspunkt. De gennemførte interviews kan da ikke direkte bruges til at kortlægge, hvilke elementer fra forskellige vidensrationaler datajournalisterne rent faktisk anvender. De kan derimod bruges til at opnå indsigt i, hvordan journalisterne selv legitimerer deres fremgangsmåder, samt hvilke regler, procedurer og overvejelser der styrer en eventuel kombination af forskellige logikker og teknikker. Gennem analyse og fortolkning tilstræbes det sidenhen at sammenstykke et billede af den mere abstrakte epistemologi bag de interviewede journalisters ageren og i nogen grad datajournalistikken som helhed.

\section{Resultater}

På grundlag af den indsamlede empiri vil det følgende afsnit beskrive indsigter vedrørende en række af de skønssituationer, som kendetegner datajournalisternes hverdag. Herved fokuseres især på fire aspekter, der løst knytter an til de ovenfor beskrevne vidensrationaler: (1) metodevalg, (2) valideringsprocedurer, (3) åbenhedspraksis og (4) journalisternes syn på interaktiv, nonlineær formidling. 


\section{Metodevalg: Mellem journalistik og videnskab}

Med hensyn til den metodiske fremgangsmåde kan det først og fremmest konstateres, at datajournalisternes grundlæggende tilgang til dataanalysen, herunder metodevalget, i høj grad synes at være styret af pragmatiske overvejelser:

Det er ikke så formaliseret. Det er ikke sådan, at vi sætter os ned på redaktionsmødet og siger: Denne her ide kræver de her data, og de her data kræver denne her metode, og denne metode kræver denne beregning [...] Det opstår mere som sådan en: Her er en idé, hvad gør vi med det?

(IP2, tv-/webmedie)

Når valget af metoder er kendetegnet ved en ad hoc-tilgang, rejser det spørgsmålet, i hvilket omfang datajournalisterne egentlig orienterer sig mod videnskabelige rationaler og logikker, som blandt andet CAR-traditionen tilsiger det. På den ene side fremhæver kun én interviewperson eksplicit og af egen drift videnskabelige normer som grundlag for vedkommendes brug af kvantitative metoder. Omvendt pointerer fire interviewpersoner i varierende grad, at deres tilgang ifølge dem ikke følger en "videnskabelig metode". På den anden side må datajournalisternes praksis dog antages at bygge på en implicit accept af nogle af de epistemologiske grundantagelser, som står centralt i både den kvantitative forskning og CAR-traditionen, herunder præmissen om, at virkeligheden kan måles, vejes og tælles (Wien, 2005: 38ff).

Ser man på de konkrete metoder, er det bemærkelsesværdigt, at interviewpersonerne synes at have svært ved at retfærdiggøre brugen af mere avancerede videnskabelige teknikker såsom statistiske modeller. Som en interviewperson formulerer det:

Min filosofi er, at jo mere avancerede metoder man skal bruge, eller man bruger, desto mere er der at forklare læserne. [...] Og det taler for, at man hurtigt kan stå med et forklaringsproblem, når man har lavet nogle meget indviklede analyser. 
En årsag kan således ligge i journalisternes publikum, der ikke kan forventes at være i stand til at fortolke og vurdere komplekse statistiske modeller (Albæk, 2006: 30). Den logiske konsekvens bliver da, at der ofte tyes til simple analysemetoder, der alt andet lige er lettere at forklare og dermed legitimere vis-a-vis brugeren.

Som en anden konsekvens af forbeholdene beskriver fire interviewpersoner, at mere avancerede analyser og følgelig også det tilhørende fortolkningsarbejde i nogen grad overflyttes til eksterne aktører:

Vi laver ikke regressionsanalyser eller den slags. Det kunne vi i princippet godt gøre. [...] Men i dag vil vi nok lægge den type analyser uden for huset [...]

(IP8, dagblad)

Selvom journalisterne ifølge citatet "i princippet" godt kunne gennemføre analyserne, kan det diskuteres, i hvilket omfang journalister egentlig råder over den specifikke viden og den metodiske rutine, som brugen af mere komplekse statistiske beregninger og analyser kræver. Der eksisterer på nuværende tidspunkt ikke nogen detaljeret undersøgelse af danske datajournalisters baggrund og statistiske færdigheder, men stort set alle interviewpersoner angiver i nogen grad at være autodidakte inden for feltet. De således forventelige begrænsninger med hensyn til ekspertise i kombination med tidspres kan da gøre det nødvendigt i nogle tilfælde at opgive en del af den "analytiske autonomi" ved at hente hjælp udefra.

Foruden at kompensere for eventuelt manglende tekniske og metodiske færdigheder opnår journalisten ved at udlicitere analyser imidlertid også en form for "kompensatorisk legitimitet", det vil sige at journalisten låner ekspertens autoritet som indehaver af neutral, faktuel viden (Albæk, 2006: 35f). På et normativt plan kan dette være tilstræbelsesværdigt, da avancerede analyser kan være svære at forene med et muligt ideal om journalisten som værende distanceret observatør (Post, 2015: 743). Mere komplekse metoder kræver flere valg, for eksempel når det handler om at sortere og filtrere data, hvilket alt andet lige tvinger journalisten ud i en mere aktiv rolle (jf. Schrager, 2014). Jo flere valg journalisten træffer, jo større er faren for, at resultatet 
fremstår som selektivt og skævvredet, og journalisten kan ikke i samme grad legitimere sin praksis ved at henvise til en rolle som passiv formidler.

Uagtet bevæggrundene kan interviewpersonernes forbehold dog tolkes som et tegn på, at der i praksis er nogle tydelige grænser for, hvor meget datajournalister i metodisk henseende kan låne fra videnskabelige discipliner uden at komme i konflikt med journalistiske rationaler og normer.

\section{Validering: Hvornår kan man stole på data og analyser?}

På baggrund af datajournalisternes tids- og ressourcemæssige begrænsninger vil det langtfra altid være muligt at validere alle data tilbundsgående (Ekström, 2002: 270). Der må sidenhen foretages et skøn vedrørende behovet for validering.

I denne forbindelse beskriver interviewpersonerne, at valideringsbehovet grundlæggende afhænger af datagrundlagets og de anvendte metoders kompleksitet såvel som en individuel vurdering af datasættet og datakilden (jf. figur 2). 
Figur 2. Skitsering af journalisternes skøn vedrørende behovet for datavalidering.

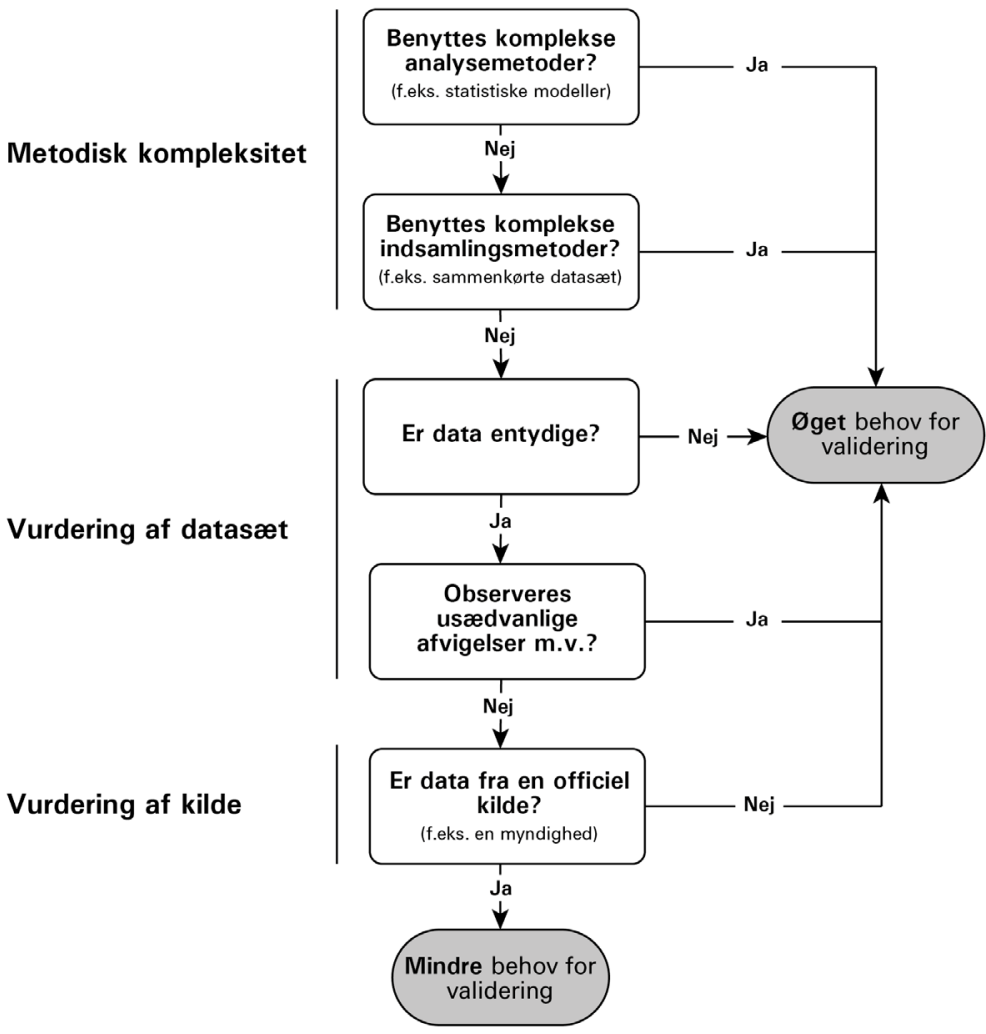

Ved metodisk simple typer datajournalistik er journalistens ansvar mere eller mindre begrænset til vurderingen af datakilden og en akkurat gengivelse af data. Det datajournalistiske produkts legitimitet beror primært på de anvendte metoders selvforklarende karakter og kildens umiddelbare troværdighed:

Når man arbejder med officielle kilder som Eurostat, FN og Danmarks Statistik [...], så går man jo ikke ind og tjekker den enkelte tabel.

I tilfælde af en høj(ere) metodisk kompleksitet og selvindsamlede data er datajournalisten derimod nødt til at forholde sig 
mere reflekterende til data og metoder. Idet journalisten her ikke kan nøjes med at henvise til datakildens autoritet, kommer vedkommende i højere grad til selv at stå til ansvar for de frembragte resultater.

Én strategi til at imødegå dette kan igen bestå i at inddrage eksterne aktører med henblik på at validere egne konklusioner og analyser. I journalisternes udtalelser fremgår det flere steder, at denne form for validering i høj grad ser ud til at være styret af "klassiske" journalistiske normer og valideringsteknikker, der også bruges i andre typer journalistik. Som eksempel nævner en interviewperson princippet om at få to uafhængige kilder til at validere data som valideringsprincip:

For mig handler det bare om: "Kan jeg validere det hos en anden kilde?" [...] Det er lidt den der klassiske journalistiske tilgang, at der skal to kilder til at verificere [...].

(IP1, dagblad/fagblad)

Inddragelsen af en "second opinion", der især omtales i forbindelse med mere komplekse analyser og data, behøver dog ikke partout at fremgå af selve produktionerne, for at sidstnævnte betragtes som tilstrækkelig legitimeret:

Det [kan] meget ofte foregå i baggrunden, at jeg ringer og siger: "Jeg har lavet denne her analyse og når frem til det og det resultat", og så hører jeg simpelthen, hvad de siger. [...] Det kan også godt være, de ikke bliver citeret, fordi man ikke skønner, at det er relevant.

Udsagnet nuancerer dermed i nogen grad ovenstående pointe om journalisternes brug af "kompensatorisk legitimitet". Inddragelsen af eksperter benyttes ikke nødvendigvis som synlig argumentationsstrategi over for brugeren ("påstand Y er troværdig, fordi den stammer fra ekspert X"). Kontakten til eksterne med henblik på at afprøve resultater kan godt være begrænset til journalisternes bagvedliggende valideringsproces. En udadtil mere synlig legitimeringsstrategi er derimod den praktiserede åbenhed. 


\section{3. Åbenhed: Mere forsvarsstrategi end open source}

På tværs af interviewpersonerne kan det konstateres, at åbenhed omtales som værende en afgørende faktor, når det handler om at legitimere datajournalistikken over for modtagerne. Åbenhed, der ofte beskrives som en grundpræmis for datajournalistikken (Coddington, 2015: 340), kommer i praksis blandt andet til udtryk ved, at journalisterne giver adgang til datasæt, linker til kilder og gør rede for de metoder og valg, der har ledt frem til et bestemt resultat (jf. Vos og Craft, 2016: 4).

Ud fra de gennemførte interviews kan åbenhedens betydning som legitimeringsstrategi imidlertid tolkes forskelligt. Det mest fremtrædende motiv bag danske datajournalisters åbenhedspraksis synes at være, at åbenhed fungerer som en slags værn:

Jeg synes, at det [åbenhed, red.] kan styrke historien, og at man kan undgå kritik. Simpelthen fordi [hvis] der er nogen, der er i tvivl om, om det nu kan være rigtigt, når man bare skriver en eller anden overordnet procent, [så kan] folk selv efterprøve det.

(IP8, dagblad)

Netop emfasen af replicerbarhed kan udlægges som bevægelse hen imod et videnskabeligt inspireret objektivitetsideal, hvor objektivitet ikke nødvendigvis står og falder med journalistens strengt passive observatørrolle (Wien, 2005: 38). Legitimitet og objektivitet opnås derimod ved, at modtageren kan reproducere resultaterne (Post, 2015: 731). Bevægelsen mod en større åbenhed mødes dog til tider også af forbehold, som for eksempel her:

Jeg tror personligt, at jeg tænker, at jeg gør mig selv sårbar, fordi når man lægger en artikel ud, har man jo ikke kunnet sikre sig $100 \%$, at alt er i orden.

(IP3, dagblad)

Følgelig synes den praktiske implementering af åbenhedsidealet i mange tilfælde at være betinget af journalistiske skøn i forhold til det konkrete projekt. Det illustreres eksempelvis af udtalelser, der fremhæver betydningen af den tilsigtede målgruppe: 
Jeg laver noget for Ugeskrift for Læger indimellem. De vil virkelig gerne have kildeangivelse på, [...] de vil gerne have mulighed for at tjekke det selv. Hvorimod hvis jeg laver noget til pædagogerne, så er de ikke så interesseret i på samme måde at efterprøve.

(IP4, freelancer)

Derudover fremgår det af de gennemførte interviews, at det oplevede behov for åbenhed godt nok synes at vokse i takt med datasættenes og metodernes kompleksitet, men at både ressourcemæssige, konkurrencemæssige og etiske hensyn (bl.a. anonymitet) trækker i den modsatte retning (jf. figur 3).

Figur 3. Faktorer med betydning for omfanget af åbenhed omkring data og metoder.

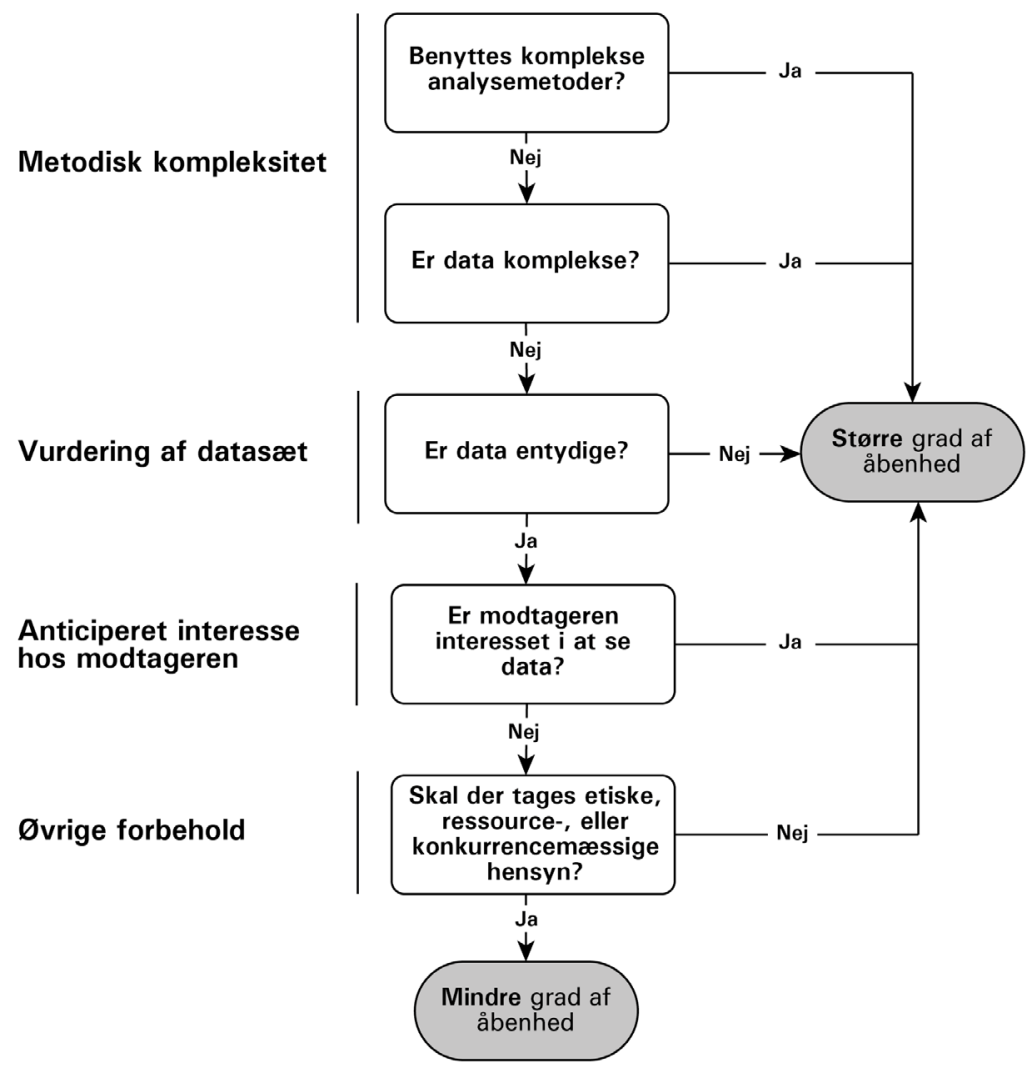


Disse forbehold medfører, at åbenheden langtfra altid er så vidtgående, at læseren faktisk kan efterligne resultaterne. Åbenhed fremstår som et "nice-to-have" frem for et ufravigeligt krav, hvilket sætter spørgsmålstegn ved, om formålet egentlig er at sikre transparens i videnskabelig forstand.

Som blandt andre Karlsson (2010) pointerer, kan åbenhed til tider også tolkes som en form for distancering og et "strategisk ritual" (Tuchman, 1972), der underbygger en klassisk journalistisk objektivitetsnorm baseret på journalistens upartiske rolle (Lesage og Hackett, 2013: 44). Ved at lægge data frem begrænser journalisten i nogen grad sit ansvar ved at overlade dele af vurderingsarbejdet til brugerne. Målet om at sikre, at andre kan efterligne dataarbejdet, er derimod af underordnet betydning (jf. Post, 2015: 741).

Mens rygdækningsmotivet uagtet disse forskellige fortolkningsmuligheder synes at være den dominerende drivkraft bag interviewpersonernes åbenhedspraksis, er de mere open sourceinspirerede ambitioner langt mere afdæmpede. På den ene side kan datajournalisternes retoriske værdsættelse af åbenhed og enkelte journalisters argumenter om, at brugerne skal kunne arbejde videre med data, tolkes som spæde tegn på, at journalisterne ser dem selv som værende en del af et større fællesskab præget af en kollaborativ ånd og en værdsættelse af vidensdeling (Lewis og Usher, 2013). Citater som det følgende antyder denne tankegang:

Vi har flere gange offentliggjort datasæt, efter vi har lavet historierne, så folk principielt kan gå dem efter i sømmene, men også arbejde videre med dem [...]

(IP6, tv-/webmedie)

Lignende open source-inspirerede argumenter nævnes på den anden side dog kun sjældent, og ingen af journalisterne kunne pege på eksempler, hvor brugere faktisk har benyttet fremlagte data, eller hvor der udtrykkeligt blev lagt op til dette fra journalisternes side. 


\section{Formidling: Den styrede interaktivitet}

Især datadrevne strømninger inden for datajournalistikken lægger i høj grad op til mere interaktive fortælleformer. Sidstnævnte kan blandt andet være kendetegnet ved, at brugeren kan interagere med omfangsrige datavisualiseringer, frem for at journalisten serverer en skarpvinklet og ofte lineær fortalt historie. Udpræget interaktivitet rykker dermed ved præmisserne for den journalistiske formidling, idet den indebærer en mere aktiv rolle for brugeren, mens datajournalistens opgave bliver at sætte rammerne for brugernes udforskning af data (Lesage og Hackett, 2013: 44; Segel og Heer, 2010). I praksis fremstår rollefordelingen mellem journalist og bruger dog mere broget.

På den ene side fremhæver flere interviewpersoner interaktivitet som et kerneelement i og én af fordelene ved datajournalistikken, der typisk ledsages af klikbare visualiseringer. På den anden side lægger flertallet af datajournalisterne vægt på, at datajournalistikken i deres øjne ikke medfører et radikalt brud med de fortælleformer, der præger den mere traditionelle journalistiks praksis og epistemologi. Ofte betones et klart behov for, at journalisten sætter nogle faste rammer for brugerens undersøgelse af data og beholder kontrollen over den journalistiske vinkel:

Det er ikke lykken at overlade for mange valg til brugerne $i$ interaktive grafikker og i analysen. De færreste kan overskue det. Journalistens rolle er stadig i datajournalistik at fortælle vinklen klart.

(IP4, freelancer)

Det er bemærkelsesværdigt, at flere interviewpersoner beskriver, hvordan der tidligere har været tale om en større entusiasme omkring muligheden for at lade brugeren udforske data. Interviewpersonerne understreger dog, at disse forsøg i deres optik ikke har båret frugt, hvorfor man har revurderet satsningen på mere brugerdrevne formidlingsformer. Eksempelvis forklarer en interviewperson: 
[I starten var det] meget ud fra ideologien "gå på opdagelse i data" [...] Men for den almindelige læser virker det overhovedet ikke. [...] Man er simpelthen nødt til at fokusere utrolig meget og sige, at det er det her i datasættet, der er vigtigt, og præsentere det.

(IP3, dagblad)

Denne udvikling kan tolkes som en tilbagevenden til mere traditionelle journalistiske normer og rutiner på bekostning af det datadrevne vidensrationale, der betoner datas iboende journalistiske værdi og værdien af at lade brugeren fortolke selv (Lewis og Westlund, 2015: 453; Parasie og Dagiral, 2012: 864). Det kan da diskuteres, hvad der ligger bag denne udvikling.

En mulig forklaring kan være, at det datadrevne vidensrationale er i direkte konflikt med kerneelementer i den journalistiske kultur og selvopfattelse. Som Mark Deuze fremhæver, er ønsket om at bevare autonomien over det journalistiske indhold og dets vinkling stærkt forandret i den journalistiske ideologi (Deuze, 2005: 456). Dette foranlediger også Seth Lewis til at udpege den professionelle ideologi og etablerede kultur som en forhindring for en mere udpræget brugerinddragelse (Lewis, 2012: 845). Ud fra en etableret konvention om, at journalisten styrer formidlingen, er det vanskeligt at legitimere formidlingsformer, der bygger på, at brugerne selv skal udforske data.

Særligt journalisternes beskrivelser af deres mislykkede forsøg med brugerdrevne formater kunne også tyde på, at brugerne enten ikke ønsker eller ikke forstår at gøre brug af diverse former for interaktivitet og brugerinddragelse (se Segel og Heer, 2010: 1147). Med hensyn til årsagen kan der imidlertid være tale om en vis hønen eller ægget-problematik. Det kan være svært at afgøre, hvorvidt en tilbageholdende brug af brugerinddragelse og interaktivitet skyldes manglende interesse på brugersiden, eller om den manglende interesse omvendt skyldes manglende bekendtskab med interaktive formidlingsformer.

\section{Konklusion}

Hvad kan de foroven skitserede overvejelser vedrørende metodevalg, valideringsprocedurer, åbenhedspraksis og interaktivitet 
overordnet fortælle om epistemologien bag danske datajournalisters arbejde?

Grundlæggende bærer de interviewede journalisters legitimeringspraksis præg af, at datajournalisterne meget pragmatisk kombinerer epistemologiske og metodologiske elementer fra flere discipliners vidensgrundlag, herunder samfundsvidenskab, it og journalistik. Pragmatismen er blandt andet tydelig, når både metodevalget såvel som graden af åbenhed og interaktivitet justeres afhængigt af faktorer som datagrundlag, produktionsvilkår og ikke mindst journalistiske formidlingskrav. Uagtet eventuelle lån fra andre discipliner og kulturer fremstår journalistiske normer som det afgørende omdrejningspunkt for datajournalisternes overvejelser, hvilket sætter tydelige rammer for importen af metoder og logikker "udefra".

Mangfoldigheden af skøn, normer og forbehold gør det generelt vanskeligt at tale om en monolitisk epistemologi. Tværtimod kan den udprægede pragmatisme tolkes som tegn på, at datajournalistikken endnu ikke har udviklet et selvstændigt erkendelsesteoretisk grundlag med heraf afledte systematiske procedurer. Det epistemologiske grundlag for datajournalisters kombination af vidensrationaler forbliver diffust.

I et professionsperspektiv rejser dette spørgsmålet, hvilken betydning datajournalistikkens multidisciplinære karakter og pragmatiske tilgang har eller kan få for den journalistiske profession som helhed. Hvis det lykkes i højere grad at integrere rationaler og metoder for arbejdet med kvantitative data i det journalistiske vidensgrundlag og den journalistiske praksis, kan dette potentielt være med til at udvide journalistikkens jurisdiktion. Arbejdet med data vil da blive en legitim "journalistisk" opgave. Lykkes det derimod ikke at basere den datajournalistiske praksis på et tilstrækkeligt solidt og erkendelsesteoretisk kohærent vidensgrundlag, kan det have mere eller mindre alvorlige implikationer. I bedste fald vil man holde sig til simple former for datajournalistik, der kan legitimeres alene ud fra gængse journalistiske logikker, rutiner og metoder. Denne praksis ville minde om den kendte brug af infografikker og cementere afhængigheden af andres dataanalyser. I værste fald vil datajournalistik opleves som værende i strid med både journalistikkens og andre 
discipliners normer, hvilket kan sætte spørgsmålstegn ved denne journalistikforms troværdighed og legitimitet.

\section{Diskussion af resultaternes generaliserbarhed}

De opridsede konklusioners gyldighed skal ses i lyset af, at der tages udgangspunkt i journalisternes eget syn på deres praksis og legitimeringen af selvsamme. Det indebærer, at konteksten og rammevilkårene for datajournalisternes arbejde kun er belyst indirekte og gennem journalisternes øjne. Ligeledes kan undersøgelsen ikke sige noget direkte om, hvorvidt andre, for eksempel brugere, chefer og faggrupper som grafikere og programmører, anser datajournalisternes praksis og produktioner som værende tilstrækkelig legitimeret. Dette tydeliggør behovet for også at inddrage andre aktører end datajournalister i fremtidige studier for at opnå et mere eksternt syn på datajournalistikkens oplevede legitimitet.

Hertil kommer, at undersøgelsen empirisk er afgrænset til en dansk kontekst. På et praktisk plan kan eksempelvis det danske mediemarkeds størrelse have betydning for, hvor mange ressourcer medier kan investere i datajournalistik, hvilket igen kan påvirke journalisternes råderum og muligheder (Fink og Anderson, 2014: 479). På et mere kulturelt plan kan bl.a. indholdet af det journalistiske rationale og de epistemologiske træk af professionskulturen variere på tværs af lande (se Hanitzsch, 2007). Det er derfor muligt, at specifikke aspekter af den danske journalistiks professionskultur, der her ikke er undersøgt i sin helhed, er en begrænsende faktor i forhold til at overføre de tilgange og tendenser, som observeres i udlandet. Fremtidige komparative studier af datajournalistikken vil her kunne fremme forståelsen af, hvordan forskellige nationale professionskulturer sætter deres præg på datajournalistikken. 


\section{REFERENCER}

Abbott, Andrew (1988). The System of Professions. An Essay on the Division of Expert Labor. Chicago: University of Chicago Press.

Albæk, Erik (2006). "Statskundskab og journalistik - et umage par?" Journalistica 3: pp. 27-43.

Brinkmann, Svend (2012). "Forståelse og fortolkning”. I Videnskabsteori $i$ statskundskab, sociologi og forvaltning, redigeret af Michael $\mathrm{H}$. Jacobsen, Kasper Lippert-Rasmussen og Peter Nedergaard, pp. 67-98. København: Hans Reitzels Forlag.

Coddington, Mark (2015). “Clarifying Journalism's Quantitative Turn”. Digital Journalism 3 (3): pp. 331-48.

Deuze, Mark (2005). "What is Journalism?: Professional Identity and Ideology of Journalists Reconsidered”. Journalism 6 (4): pp. 442-64.

Ekström, Mats (2002). "Epistemologies of TV Journalism - A Theoretical Framework” 3 (3): pp. 259-82.

Fink, Katherine og C.W. Anderson (2014). "Data Journalism in the United States”. Journalism Studies 9699 (April 2015): pp. 1-15.

Greene, Taylor (2015). “Common Values Unite Journalism and Open Source”. opensource.com/life/15/8/common-values-unite-journalismopen-source (hentet 27.7.17).

Grimen, Harald (2008). "Profesjon og kunnskap”. I Profesjonsstudier, redigeret af Anders Molander og Lars Inge Terum, 2.udg., pp. 71-86. Oslo: Universitetsforlaget.

Grimen, Harald og Anders Molander (2008). “Profesjon og skjønn”. I Profesjonsstudier, redigeret af Anders Molander og Lars I. Terum, 2.udg., pp. 179-96. Oslo: Universitetsforlaget.

Hanitzsch, Thomas (2007). "Deconstructing Journalism Culture: Toward a Universal Theory”. Communication Theory 17 (4): pp. 367-85.

Karlsson, Michael (2010). "Rituals of Transparency". Journalism Studies 11 (4): pp. 535-45.

Lesage, Frédérik og Robert A. Hackett (2013). "Between Objectivity and Openness - The Mediality of Data for Journalism”. Media and Communication 1 (1): pp. 39-50.

Lewis, Seth C. (2012). “The Tension Between Professional Control and Open Participation”. Information, Communication \& Society 15 (6): pp. 836-66.

Lewis, Seth C. og Nikki Usher (2013). "Open Source and Journalism: Toward New Frameworks for Imagining News Innovation”. Media, Culture \& Society 35 (5): pp. 602-19. 
Lewis, Seth C. og Oscar Westlund (2015). "Big Data and Journalism”. Digital Journalism 3 (3): pp. 447-66.

Meyer, Philip (1973). Precision Journalism: A Reporter's Introduction to Social Science Methods. 2. ed. Bloomington: Indiana University Press.

Meyer, Philip (1991). The New Precision Journalism. Bloomington: Indiana University Press.

Parasie, Sylvain (2015). “Data-Driven Revelation?” Digital Journalism 3 (3): pp. 364-80.

Parasie, Sylvain og Eric Dagiral (2012). "Data-driven Journalism and the Public Good: 'Computer-assisted-reporters' and 'Programmerjournalists' in Chicago”. New Media \& Society 15 (6): pp. 853-71.

Post, Senja (2015). "Scientific Objectivity in Journalism? How Journalists and Academics define Objectivity, Assess its Attainability, and Rate its Desirability”. Journalism 16 (6): pp. 730-49.

Schrager, Allison (2014). “The problem with data journalism”. Qz.com. qz.com/189703/the-problem-with-data-journalism/ (hentet 27.7.17).

Segel, Edward og Jeffrey Heer (2010). "Narrative Visualization: Telling Stories with data". IEEE Transactions on Visualization and Computer Graphics 16 (6): pp. 1139-48.

Svith, Flemming (2014). “Grundlaget for journalisters viden”. I Professioner under pres, redigeret af Gitte S. Harrits, Martin B. Johansen, Jens E. Kristensen, Lars T. Larsen og Søren G. Olesen, pp. 119-46. Aarhus: Systime.

Tuchman, Gaye (1972). “Objectivity as Strategic Ritual: An Examination of Newsmen's Notions of Objectivity". The American Journal of Sociology 77 (4): pp. 660-679.

Vos, Tim P. og Stephanie Craft (2016). "The Discursive Construction of Journalistic Transparency”. Journalism Studies, februar, pp. 1-18.

Wien, Charlotte (2005). "Journaivismen og positivlistikken”. Nordicom Information, nr. 2: pp. 37-46.

\section{FORFATTER}

Boy Rasmus Repenning

Cand.public., webproducer, Jyllands-Posten.

repenning@gmx.de 